\title{
Liberalna demokracja jako obóz koncentracyjny? Kilka uwag o mnożących się (skandalicznych?) opiniach
}

Badając ongiś proces kształtowania się znaczenia kategorii „suwerenność”, podążyłem nie tylko (śladem wielu) ku uwagom postglosatorów, osobliwie Baldusa de Ubaldisa z XIV w., lecz także (śladem jeszcze liczniejszych) ku ustaleniom Jeana Bodina, a później (mniej znanego) Charlesa Loyseau. Wydawało mi się, że każdy z wymienionych przygotowywał ten sposób myślenia, który najklarowniej przedstawił w połowie XVII w. Thomas Hobbes, każdy z nich bowiem pragnął ujawnić, a może i rozwiązać, problem „wyłączności prawodawczej” pewnej grupy jako znaku jej odrębności politycznej. Co więcej, wydawało mi się, że w każdym przypadku, także u Hobbesa, szło nie tyle o odnalezienie momentu jurydycznej decyzji, ile o wskazanie podmiotu albo „podmiotu” mającego decyzję tę podejmować - gdy Baldus analizował wagę prawa dla państw-miast, republik północnowłoskich, gdy Bodin opowiadał o rozkazie, który ma być wydawany przez jeden podmiot, najlepiej króla, gdy Loyseau łączył wyłączną możność rozkazywania z jej aktualizacją przez kogoś, kto przypominać miał „pana feudalnego" (sprawującego dominium, a nie tylko imperium), gdy wreszcie (wbrew utrwalonej w literaturze polskojęzycznej tradycji) zastanawiałem się nad państwem, nieco abstrakcyjnie ujmowanym, jako źródłem, z którego „wypływać" miały normy prawa natury, prawa rozumu albo prawa państwowego, wciąż „odpominałem” pewną ważną tradycję antyczną, przedchrześcijańską. Mimo wszelkich zahamowań wynikających z kojarzenia wymienionych z podejściem bliskim raczej m.in. św. Augustynowi niźli „,chrześcijańskim arystotelikom”, krytycznie spoglądającym na „wyrzucanie moralności z polityki”, czynienie pierwszym jakiegoś ładu normatywnego, niepochodzącego od człowieka lub z organu piastowanego przez człowieka, „odpominałem” jedną z kluczowych dystynkcji 
zostawionych przez Arystotelesa: dystynkcji zwierzęcia i człowieka, także wszak będącego dla Stagiryty w pewnym zakresie zwierzęciem, atoli politycznym, a nie „po prostu" i „tylko".

Tą drogą, choć nie tylko, docierałem do niezwykle istotnych — jak się wydaje - pytań zajmujących historyka myśli politycznej: po pierwsze o umocowanie (lub jego brak) aktywności wydającego rozkaz, w innym sformułowaniu o normatywne (pozaprawne, ale jednak nie faktyczne, lecz normatywne właśnie) ugruntowanie aktywności prawodawczej; po drugie zaś, choć już tylko wtórnie, o ewentualną wtórność prawa pochodzącego od wydającego ów rozkaz.

Arystoteles zauważał, że w „piątym rodzaju demokracji” demagodzy (,„pochlebcy ludu", podobni pochlebcom monarchów) rządzą przy pomocy uchwał zamiast realizować „rządy prawa” (choć uchwały podejmowane były przez lud, to demagodzy decydowali ostatecznie o zdaniu ludu; nie trzeba było czekać na Schumpetera i podobnych mu analityków aktywnych w XX w., by dostrzec problem — nie wola ludu jest istotna, ale raczej wola tych, którym ten się podporządkowywał; uwaga ta jest o tyle istotna, że oddaje osobliwe „przeniesienie” źródła uchwał z ,podmiotu zbiorowego”, który formalnie je podejmuje, na rzeczywisty podmiot, który wpływa lub kształtuje treść woli wyrażanej w uchwałach $)^{1}$. Pomijając dywagacje Stagiryty o problematyczności traktowania tego „rodzaju demokracji” jako ustroju, dostrzeżmy, iż gdy większość włada przy pomocy uchwał przyjmowanych ad hoc, nie stanowiąc norm wiążących „na dłużej i niezależnie od okoliczności”, to należy mówić nie tyle o demokracji, ile o bieżących „rządach ludu, którego wola wolna jest od wędzideł prawa". Oto, jak się wydaje,

${ }^{1}$ To, czy ten „nowy podmiot”, stojący u źródła uchwał, jest bardziej interesowny niż „,uczestnicy ludu", może być kolejnym przedmiotem analiz; dla nas istotniejsze jest to, że Stagiryta powiada: „słusznie więc, jak się zdaje, można by tu podnieść zarzut, że taka demokracja [analizowana w jej »piątym rodzaju« — przyp. B.S.] w ogóle nie jest ustrojem, bo gdzie prawa nie rządzą, tam nie ma ustroju. Prawo bowiem musi panować nad wszystkim, w poszczególnych zaś wypadkach winny rozstrzygać władze i tylko [tam], gdzie się tak dzieje, winna być mowa o ustroju. Jeśli więc demokracja jest jednym z ustrojów, to oczywiście taki stan rzeczy, przy którym wszystko się załatwia uchwałami, nie jest właściwie wcale demokracją, żadna bowiem uchwała nie może tu mieć charakteru ogólnej normy" (Arystoteles, Polityka, przeł. L. Piotrowicz, [w:] idem, Dzieła wszystkie, t. VI, Warszawa 2001, s. 1292a). Wynika z tego, że demokracja, której znamieniem są „rządy uchwał”, a nie prawa, „rządy decyzji” podejmowanych przez lud być może pod wpływem jego „pochlebców”, wcale nie jest ustrojem, nie jest więc demokracją, o ile ta ma być ustrojem. Wspominając ataki dwudziestowiecznych normatywistów prawniczych na XIX- i XX-wiecznych pozytywistów prawniczych, możemy orzec, że już dawno argumenty stosowane w tych atakach zostały przewidziane: problem istnienia ustroju tkwi w panowaniu prawa wiążącego tych, którzy podejmują uchwały. Jeśli prawo nie panuje, jeśli nie wyznacza granic dla podejmujących uchwały, jeśli uchwały podejmowane są bez takiego wiążącego kontekstu normatywnego, jeśli w końcu one tylko ustalają treść norm wiążących, wówczas nie może już być mowy o ustroju, nie może być mowy o demokracji (chciałoby się postawić kwestię: czy pozytywiści usuwający taki kontekst byliby, zdaniem Arystotelesa oczywiście, w stanie działać w demokracji jako ustroju?; czy uzasadnialiby w jakikolwiek sposób trwanie demokracji jako ustroju, czy raczej działaliby w demokracji, która ustrojem już nie jest, w której pozostaje nazwa jedynie, ale nie ustrój). 
jeden z ważniejszych wniosków wynikających z poszukiwań Arystotelesa — jeśli w miejsce prawa wstępują uchwały, jeśli mamy do czynienia tylko z bieżącym rządzeniem przez większość przy pomocy uchwał podejmowanych przez zbiorowego prawodawcę, ewentualnie powodowanego przez pochlebców-demagogów, to na treści tych uchwał wspiera się to, co można nazwać (na użytek niniejszego tekstu) „ładem podstawowym” zbiorowości, a może nawet jego „konstytucją”2. Okazuje się bowiem, że skutkiem „przestawienia”, polegającego na „postawieniu" uchwał przed prawem, jest podporządkowanie woli większości wszelkich norm, także tych, które są ,,równomiernie właściwe”, „korzystne dla całego państwa i ogółu obywateli”, których „według najlepszego ustroju” pragną słuchać wszyscy i rządzić się nimi gwoli „urzeczywistnienia życia cnotliwego", które warunkują istnienie wspólnoty politycznej ${ }^{3}$, „współżycie” w jej ramach, a nadto — co ważne - „piękne uczynki” ${ }^{4}$. Skoro, wywodził Stagiryta w innym miejscu: „Polityki, we wszystkich umiejętnościach i sztukach celem jest dobro, a nawet tak jest przede wszystkim i w najwyższym stopniu w najważniejszej ze wszystkich [umiejętności], jaką jest umiejętność sprawowania władzy w państwie", to czy w uchwałach ludu powodowanego przez demagogów-pochlebców może zostać ustalona treść dobra, może być realizowana umiejętność, jaką ma być polityka? Może uchwały te „ustanawiały” raczej to, co przez „,dobro” rozumieli demagodzy, a za nimi lud? ${ }^{5}$

Grecki myśliciel za główny cel poszukiwań uznawał rozeznawanie warunków dobrego życia istniejącej, trwającej wspólnoty politycznej: to, co indywidualne, partykularne miało być podporządkowywane temu, co wspólne, a „dobra partykularnego" nie można było zestawiać z tamtym, wspólnotowym dobrem; nie można było w imię ,dobra niższego rzędu”, znajdowanego na poziomie jednostki czy grupy, na poziomie składowych wspólnoty, a nawet na poziomie ewentualnie interesownego demagoga, przeczyć dobru wyższego rzędu — istnienie całości było ważniejsze niż istnienie jego składowych ${ }^{6}$.

${ }^{2}$ Zob. szerzej B. Szlachta, O problematyczności uchwat ludu jako źródeł prawa (na przykładzie Polityki Arystotelesa), [w:] Polska-Europa-świat. Prace politologiczne i historyczne. Księga jubileuszowa ofiarowana Profesorowi Edwardowi Olszewskiemu z okazji 70. rocznicy urodzin, red. M. Marczewska-Rytko, S. Stępień, Lublin 2012, s. 35-47.

${ }^{3}$ Arystoteles, op. cit., s. 1284a.

${ }^{4}$ Ibidem. Skoro, kontynuuje Arystoteles, ,prawa powinny być dostosowane do ustroju, to oczywistą jest rzeczą, że prawa dostosowane do właściwego ustroju będą z konieczności sprawiedliwe, a przystosowane do zwyrodniałego ustroju niesprawiedliwe" (ibidem, s. 1282b).

${ }^{5}$ Ibidem.

${ }^{6}$ Te ważne ustalenia, pochodzące z IV w. przed Chrystusem, mają znaczenie także dzisiaj, choć Arystoteles nie znał „państw narodowych” starających się zachować istnienie w globalizującym się świecie, uwzględniającym obok tendencji integracyjnych dotyczących całego globu lub poszczególnych jego regionów także tendencje przeciwne, oparte już to na tezie o wielokulturowości, już to na tezie o potrzebie przechowywania odrębności regionalnych. 
„Odpominanie” Stagiryty towarzyszyło namysłowi nad ujęciami wczesnonowożytnymi — badając „potencjalny decyzjonizm polityczno-prawny”, sytuowany wobec każdej aktywności prawodawcy jako piastuna suwerenności, powracałem do uwag o potrzebie uwzględniania i akcji prawodawcy (uchwał ludu), i prawa relacjonowanego do poszukiwania (i zapewne utrwalania) treści dobra; to, co polityczne, było tedy łączone ze stanowieniem norm o walorze prawnym, które coraz wyraźniej traciły fundament umiejscawiany w koncepcji dobra kojarzonego z „formą gatunkową” (co, w pewnym zakresie naśladując czy kontynuując zwłaszcza Platona, miał analizować Stagiryta). Nie wdając się w analizę problemów wynikających z „rewolucji nominalistyczno-woluntarystycznej” XIV i kolejnych stuleci po Chrystusie, dopowiem jedynie, że konsekwencją był w jakimś zakresie zanik „momentu kontemplacyjnego" polityki, kierującego ku rozpoznawaniu „,natury” czy ,istoty gatunkowej”, kojarzonych z „gatunkową formą", albo ku rozpoznawaniu norm opartych na zwyczaju, woli Boga jako prawodawcy, woli człowieka uwzględniającego orzeczenia jego rozumu przyrodzonego, a nawet „ducha praw” lub „ducha narodu”. Każde z tych ujęć, każda z tych propozycji, w jakiejś mierze nawiązywała do dystynkcji Arystotelesa uchwał i prawa, wiązała drugie nie $\mathrm{z}$ aktualną wolą wyrażaną w uchwałach (być może sprokurowanych przez demagogów-pochlebców albo narzucającego swą wolę arbitralnego króla działającego ku spełnieniu własnego „interesu”), ale z jakimś mniej lub bardziej osobliwym przedmiotem poznania, który miał być uchwycony zapewne przez rozum prawodawcy i potwierdzony przez jego wolę.

Problem jednak w tym, że podobne wymaganie jest coraz rzadsze w nowożytności; że u schyłku XX w., po straszliwych doświadczeniach Auschwitz i Kołymy, władzę (również, jak się wydaje, prawodawczą) wciąż można kojarzyć $\mathrm{z}$ wiedzą lub umiejętnością, jednak nie z tą, która wynika z rozeznania, lecz z tą, która wynika z relacji z innymi; być może nawet z tą, która jest tylko użyteczna dla woli panowania. Gdy czytamy u Michela Foucaulta, zaliczanego do grona najbardziej znanych myślicieli drugiej połowy XX w.,

że nie ma takich historycznych form władzy, których nie dałoby się analizować w terminach panowania jednych nad drugimi, że każde prawo, wszystko jedno czyje, że każda forma władzy, wszystko jedno jaka, że każdy typ rządów można analizować nie w kategoriach prawa naturalnego i ustanawiania suwerena, lecz jako nieskończony — i nieskończenie historyczny — ruch stosunków panowania jednych nad drugimi ${ }^{7}$,

${ }^{7}$ M. Foucault, Trzeba bronić spoleczeństwa. Wyktady w Collège de France, 1976, przeł. M. Kowalska, Warszawa 1998, s. 115 i 117. Mimo kontrowersyjności sformułowanej przez Foucaulta interpretacji Hobbesa, w koncepcji którego suweren miałby być podmiotem „czystego panowania - władzy”, nie zaś tym, który bezinteresownie rozeznaje „treść rozumu, czyli normy prawa natury" i - zaopatrzywszy je w sankcję — wymusza respekt dla tych norm od każdego poddanego powodującego się — podobnie jak w stanie natury — „czysto partykularnym” instynktem samozachowawczym, warto wskazać nie tylko to, że Foucault znajduje „dyskurs o czystym panowaniu" jako nowy w XVII w., a nie dopiero trzy stulecia później, ale także to, że w jego ujęciu ta ,czysta władza” wiąże się bezpośrednio i nierozerwalnie z wiedzą. Należałoby zapytać: z wiedzą 
to namysł Stagiryty uznać musimy za przebrzmiały, utracony, unieważniony nawet. Nie idzie o to, że myśl Foucaulta zawiera wołanie o przywrócenie ,politycznego historycyzmu" zablokowanego wpierw przez Hobbesa, a potem przez dialektyczny materializm marksistów, o usunięcie z jednej strony kontekstu prawa natury, z drugiej zaś kontekstu suwerenności, lecz o to, że wymaga ona uchwycenia władzy jako „czystego panowania”, które pozbawiane jest kontekstu normatywnego. Krytykując ,tyranię globalnych dyskursów z całą ich hierarchią i ze wszystkimi przywilejami teoretycznych awangard"8, Foucault zwraca się ku „genealogiom wiedzy”, łączącym wiedzę erudycyjną z lokalną pamięcią, by dzięki nim ukonstytuować ,historyczną wiedzę o walkach i wykorzystywać tę wiedzę w aktualnych taktykach”. Budowanie owych genealogii, dokładniej zaś oparcie na swoistej ,archeologii wiedzy” szczególnej „taktyki genealogicznej”, nie ma prowadzić do przeciwstawienia ,abstrakcyjnej jedności teorii” jakiegoś rodzaju „konkretnej wielości faktów”; nie idzie też o to, by:

odrzucić element spekulatywny i przeciwstawić mu, w formie jakiegoś scjentyzmu, ścisłość dobrze ustalonych informacji, bowiem projekt genealogiczny nie posiłkuje się empiryzmem i nie idzie śladami pozytywizmu w zwykłym sensie słowa. W gruncie rzeczy chodzi o to, by wiedzę lokalną, nieciągłą, zdyskwalifikowaną, nieprawomocną rozegrać przeciwko jednolitej instancji teoretycznej, która ma pretensje do sublimowania, hierarchizowania, porządkowania tej wiedzy w imię prawdziwego poznania, w imię praw nauki, jaką ponoć posiedli niektórzy. Genealogie nie są więc pozytywistycznymi powrotami do bardziej uważnej albo ściślejszej formy nauki. Dokładnie rzecz ujmując, genealogie są antynaukami ${ }^{9}$.

To charakterystyczne wyznanie sformułowane przez myśliciela, który może zostać uznany za równie nieprzychylnego filozofii polityki, jak poprzedzający go pozytywiści, służy jako uzasadnienie bliskiego mu wezwania do „buntu wiedzy”:

nie tyle przeciwko treściom, metodom lub pojęciom jakiejś nauki, ile w pierwszym rzędzie przeciwko efektom centralistycznej władzy, związanej z instytucją i funkcjonowaniem zorganizowanego dyskursu naukowego w społeczeństwie takim jak nasze [tzw. francuskie połowy lat 70. XX w. - przyp. B.S. ${ }^{10}$.

Foucault powiada wprost, że ,genealogia powinna wypowiadać walkę wszystkim efektom władzy związanym z istnieniem dyskursu, który uważa się za naukowy"11, nie tylko zatem dyskursu pozytywistycznego, lecz także — co zaznacza - marksistowskiego i innego „naukowego”, w tym - co charakterystyczne — równie skażonego „ekonomizmem” jak marksizm, dyskursu Hobbesa,

o czym lub wiedzą czego? Czy Hobbes i marksiści rozważający problem panowania uwzględniają jakąś wiedzę i pragną ją (przy użyciu władzy) narzucić? Wydaje się, że posiadają wiedzę. Dokonując jednak swoistej „redukcji” lub „blokowania”, zwracając się przeciwko „politycznemu historycyzmowi”, odrywają „czyste panowania” od faktycznego historycznego zakorzenienia.

${ }^{8}$ Ibidem, s. 21.

9 Ibidem.

${ }^{10}$ Ibidem.

${ }^{11}$ Ibidem, s. 21-22. 
fundującego „liberalną koncepcję władzy politycznej”. Przeciwko wszelkim „ekonomicznym” koncepcjom władzy Foucault pragnie przeprowadzić „,analizę nieekonomiczną", ogniskującą się na dwóch tezach:

[po pierwsze, że] władzy nie daje ani się jej nie wymienia, ani nie odzyskuje, ale że władzę się sprawuje i że istnieje ona tylko w akcie; po drugie zaś, że władza nie jest pierwotnie utrzymywaniem i odtwarzaniem stosunków ekonomicznych, lecz nade wszystko stosunkiem siły ${ }^{12}$.

W ten sposób Foucault dochodzi do znaczącej konstatacji dotyczącej istnienia dwóch, zasadniczo odmiennych, dyskursów o władzy, dwóch wielkich systemów jej analizy:

Pierwszy, stary system, który znajdziecie u filozofów XVIII w., opierał się na centralnym pojęciu władzy jako pierwotnego prawa, które człowiek odstępuje suwerenowi, oraz na pojęciu umowy jako matrycy władzy politycznej. Kiedy ustanowiona w ten sposób władza przekracza swoje uprawnienia, czyli narusza terminy umowy, władza zamienia się w ucisk. Mamy tu zatem do czynienia z koncepcją władzy jako wyniku umowy, której granicą, a raczej przekroczeniem granicy, jest ucisk. I mielibyśmy też drugi system, który próbuje, przeciwnie, analizować władzę polityczną nie według schematu umowa-ucisk, ale według schematu wojna-represja. Represja nie jest tu tym samym, czym ucisk był w stosunku do umowy, lecz zwykłym skutkiem i zwykłym wyrazem stosunku dominacji. Represja nie byłaby niczym innym jak narzucaniem pewnego stałego stosunku sił w łonie pseudopokoju, trawionego przez permanentną wojnę. Mamy więc dwa schematy analizy władzy: schemat umowa-ucisk, który jest, by się tak wyrazić, schematem prawnym, i schemat wojna-represja lub dominacja-represja, w którym właściwa opozycja nie dzieli, jak w poprzednim schemacie, działań prawnych od bezprawnych, ale walkę od podległości ${ }^{13}$.

Zaznaczmy, że Foucault - wbrew powszechnej opinii - nie uznaje Machiavellego i Hobbesa za twórców drugiego schematu, za „teoretyków wojny w społeczeństwie obywatelskim", obu przypisuje raczej schemat pierwszy, ten, który korzysta z formuł prawnych, a nawet prawa jako takiego (nie tylko zatem aktów prawnych, ale całości ,aparatów, instytucji, przepisów, przez które prawo się stosuje"), by ukryć fakt i konsekwencje dominacji króla nad poddanymi. Zgodnie z tym schematem prawo ,jest nośnikiem i sposobem urzeczywistniania stosunków niebędących stosunkami suwerenności, lecz stosunkami dominacji”, związanymi nie tyle z ogólnym faktem dominacji jednego człowieka nad innymi albo jednej grupy nad drugą, ile z licznymi i rozmaitymi formami dominacji, jakie mogą zachodzić na łonie społeczeństwa:

nie myślę tu więc o królu z jego centralną pozycją, ale o poddanych w ich wzajemnych stosunkach, nie o suwerenie w jego jedynej siedzibie, ale o wielorakich stosunkach podległości, jakie powstają w ciele społecznym ${ }^{14}$.

12 Ibidem, s. 27

13 Ibidem, s. 29-30.

14 Ibidem, s. 36. 
Zatem nie suwerenność (w rozumieniu prawodawstwa choćby opartego jak w krytyce Stagiryty — na „uchwałach ludu”, być może powodowanego przez demagogów-pochlebców) i korespondujące z nią posłuszeństwo, lecz dominacja i podporządkowanie - oto centralne zagadnienie analizowane przez Foucaulta, z którym wiąże się kwestia sprzężenia władzy i wiedzy (umacniającej dominację, a nie suwerenność). Nie regularne i legalne formy władzy, ich ogólne mechanizmy i skutki, lecz władza u swych, prawnie niedookreślonych, granic w jej lokalnych, najdalszych więc rozgałęzieniach, tam, „gdzie staje się włoskowata”; nie to, kto ma władzę i jakie są jego intencje, lecz faktyczne praktyki każdej władzy; nie jak u Hobbesa - ustalenie, w jaki sposób z wielości woli powstaje suweren lub jedna całość z nim jako jej duszą, lecz wskazanie „wielu peryferyjnych ciał, które za sprawą efektów władzy zostają ukonstytuowane jako podmioty, jako Ja" miało się stać przedmiotem analizy. Wreszcie nie władza jako zjawisko ogólnej i jednorodnej dominacji jednego lub jednych nad drugimi, lecz władza jako

coś, co krąży, a raczej coś, co funkcjonuje tylko w łańcuchu, nie dając się przywłaszczyć nikomu niby towar, bowiem władza funkcjonuje, władzę sprawuje się w sieci, a po tej sieci jednostki nie tylko krążą, ale też zawsze znajdują się w pozycji, która każe im zarazem władzy podlegać i ją sprawować. Nigdy nie są bezwładnym czy bezwolnym obiektem dla władzy, zawsze są jej trybami. Inaczej mówiąc, władza przechodzi przez jednostki, a nie po prostu się do nich odnosi ${ }^{15}[\ldots]$ wytwarza podmioty-poddanych w procesach wartych badania daleko bardziej niż geneza suwerena ${ }^{16}$.

\section{Porzucenie zaproponowanego przez Hobbesa „modelu Lewiatana”:}

sztucznego człowieka, będącego jednocześnie stworzonym automatem i jednolitą całością, który obejmuje wszystkie rzeczywiste jednostki, którego ciałem są obywatele, a duszą suweren, pozwoli na badanie władzy poza polem wyznaczonym przez prawną suwerenność i instytucję państwa ${ }^{17}$;

pozwoli na dostrzeżenie, że od XVII i XVIII w. kształtowała się „,nowa mechanika władzy”, „absolutnie niedająca się pogodzić ze stosunkami suwerenności”, zwana przez Foucaulta „dyscyplinarną”18. „Dyskurs dyscyplinarny nie ma nic wspólnego $\mathrm{z}$ dawnym dyskursem prawnym i z pojęciem reguły jako wyniku suwerennej woli" — dopowiada francuski autor. Dzieje się tak, zauważmy, bo w wyjaśnieniu tym skrywa się główna racja związku wiedzy z władzą, albowiem:

dyscypliny tworzą dyskurs, w którym mowa o regule, ale nie jest to pochodząca od suwerena reguła prawna, lecz reguła naturalna, tzn. norma. Definiują one kodeks, który nie jest

\footnotetext{
15 Ibidem, s. 38-39.

16 Ibidem, s. 54.

17 Ibidem.

18 Ibidem, s. 43-45.
} 
kodeksem prawnym, lecz kodeksem normalizacji i z konieczności odwołują się do horyzontu teoretycznego, którym nie jest gmach prawa, lecz pole nauk o człowieku. A właściwa tym dyscyplinom jurysprudencja przybiera postać wiedzy klinicznej ${ }^{19}$.

Często wyrażana obawa we współczesnych krytykach, iż normy prawne (pochodzące od suwerena) stają się systemem normatywnym respektowanym powszechnie, bo zaopatrzonym w sankcję przez tegoż suwerena (jak u Hobbesa, choć zapewne należałoby uwzględnić jego kłopot z ,przejściem” od państwa do jego reprezentanta, od „prawa państwowego”, będącego zarazem „prawem natury” i „prawem rozumu”, do orzeczenia norm przez „kogoś”), zostaje zastąpiona przez Foucaulta tezą, zgodnie z którą nie tyle normy prawne, ile „normy faktyczne" - zawarte w "kodeksie normalizacji” - stają się regułami systemu pętającego jednostki daleko bardziej niż normy prawne, bo działającego na nie „włoskowato" i „dyscyplinująco”. Przeciwko temu dojmującemu wręcz zniewoleniu niepodobna zwracać się ku dawnym ujęciom,

aby walczyć z dyscypliną, a raczej z władzą dyscyplinarną, w poszukiwaniu jakiejś władzy niedyscyplinarnej, nie należy zwracać się w stronę starego prawa suwerenności, ale szukać nowego prawa, które miałoby charakter antydyscyplinarny, ale które byłoby zarazem wolne od zasady suwerenności ${ }^{20}$.

Prawo przestaje już być „pacyfikacją”, bo pod jego powierzchnią, „,wewnątrz wszystkich, nawet najbardziej regularnych, mechanizmów władzy nadal szaleje wojna". W pewnej mierze (podobnie jak u decyzjonistów) wojna jest traktowana jako motor „,instytucji i porządku: we wszystkich trybach pokoju toczy się głucha wojna. [...] Nie istnieje neutralny podmiot" (o którym, jak się wydaje, marzył Hobbes). „Każdy jest z konieczności czyimś przeciwnikiem, bowiem społeczeństwo ma strukturę binarną" 21 .

Foucault nie poprzestaje jednak na tych konstatacjach: nie tylko traktuje wojnę jako opisany „motor” — jak ongiś instynkt samozachowawczy u Hobbesa — zatem istnieje ,jedyna zasada” tłumacząca i uzasadniająca pewną ,racjonalistyczną teorię polityczną", krytycznie ocenianą przez Oakeshotta. Obok „władzy dyscyplinarnej" pojawia się w jego rozważaniach analiza innej jeszcze formy władzy, określanej mianem „biowładza”. Oto, co pisze:

jednym z fundamentalnych zjawisk XIX w. było, jest, to, co można nazwać rozciągnięciem się władzy na życie lub, jeśli wolicie, rozciągnięciem się władzy na człowieka jako istotę żywą, swego rodzaju etatyzacja biologiczności, a przynajmniej pewna skłonność prowadząca do tego, co można by nazwać etatyzacją biologiczności ${ }^{22}$.

\footnotetext{
19 Ibidem, s. 47.

${ }^{20}$ Ibidem, s. 48.

${ }^{21}$ Ibidem, s. 59.

22 Ibidem.
} 
O ile w „klasycznej” teorii suwerenności „prawo życia i śmierci było jednym z zasadniczych atrybutów suwerena”, miał on bowiem możność „skazywania na śmierć i zezwalania na życie", o tyle już w XIX w. pojawia się odmienne prawo po stronie władzy, ale już niekojarzonej z suwerenem relacjonowanym do prawa - teraz ten, kto włada, zyskuje nowe prawo (tej kategorii wciąż używa Foucault, mimo że przeczy uwikłaniu piastuna władzy w relacje prawne), mianowicie prawo „skazywania na życie i zezwalania na śmierć" ${ }^{3}$. Nowa „technologia władzy”, obejmująca, a nie wykluczająca technikę dyscyplinarną, zyskuje zwiększoną siłę dzięki tamtej, leży już jednak na innym poziomie niż ona i posiłkuje się innymi narzędziami; co najważniejsze jednak:

\begin{abstract}
w odróżnieniu od dyscypliny, która odnosi się do ciała, nowa, niedyscyplinarna technika władzy odnosi się do ludzkiego życia, zwraca się nie do człowieka-ciała, lecz do człowieka żyjącego, do człowieka jako istoty żywej. [...] [O ile] dyscyplina próbuje rządzić wielością ludzi, o ile ta wielość może i powinna rozłożyć się na indywidualne ciała, które trzeba nadzorować, tresować, wykorzystywać, ewentualnie karać, [...] [o tyle nowa technologia władzy] odnosi się do wielości ludzi nie jako do wielości rozkładającej się na wiele ciał, lecz, przeciwnie, o tyle, o ile tworzy ona globalną masę, której dotyczą ogólne procesy właściwe życiu, takie jak narodziny, śmierć, produkcja, choroba itd. Tak więc po pierwszym zawładnięciu ciała, które dokonało się według modelu indywidualizacji, mamy drugie zawładnięcie, które nie jest już indywidualizujące, ale umasawiające, które zwraca się nie do człowieka-ciała, ale do człowieka-gatunku. Po anatomopolityce ludzkiego ciała, stworzonej w ciągu XVIII w., pojawia się, pod koniec tego samego stulecia, coś, co nie jest już anatomopolityką ludzkiego ciała, ale [to,] co nazwałbym „biopolityką" ludzkiego gatunku, która pozwala na decydowanie o takich procesach, jak proporcja urodzin i zgonów, wskaźnik reprodukcji, płodność danej populacji itp. ${ }^{24}$
\end{abstract}

Czy to ujęcie ma jeszcze cokolwiek wspólnego z klasycznym ujęciem obejmującym aspekty teoretyczny i praktyczny, refleksję nad tym, co powszechne i wyznaczające treść dobra? Czy w ujęciu myśliciela drugiej połowy XX stulecia wyłącznie negatywny charakter funkcji sprawowanej przez władzę nie zostaje wzmocniony tezą, iż piastun władzy ustala już nie tylko „zasady elementarnej sprawiedliwości”, lecz skazuje na życie i zezwala na śmierć, decydując tym samym arbitralnie o składzie populacji poddanej jego władztwu? Czy polityka w rozumieniu Arystotelesa jest jeszcze możliwa, skoro traci odniesienie już nie tylko do tego, co teoretycznie uchwytne, lecz także do tego, co stanowi umiejętność praktycznego regulowania elementarnego pokoju? Powtórzmy, czy polityka w klasycznym ujęciu, a nawet w ujęciu św. Augustyna, jest jeszcze możliwa? Czy pojęcie „polityka” zachowuje któreś z dawnych znaczeń, gdy:

poniżej poziomu tej wielkiej, absolutnej, dramatycznej i mrocznej władzy, jaką była władza suwerena, która polegała na możliwości skazywania na śmierć, pojawia się teraz, wraz z tą technologią biowładzy, tą technologią władzy „nad” populacją jako taką, nad człowiekiem jako istotą żywą, pewna ciągła, uczona władza, która ma możliwość „,skazywania na życie”?25

${ }^{23}$ Ibidem, s. 237-238.

${ }^{24}$ Ibidem, s. 240.

25 Ibidem, s. 244. 
Podobne pytania można mnożyć. Można debatować o tym, na ile Foucault uznał już, iż jednostka została okiełznana, i przeszedł do analizy okiełznania gatunku, na ile zaś jego (krytyczni) kontynuatorzy, jak choćby Giorgio Agamben, prowadzą „,biopolityczną refleksję” o jednostkach jednak — o „pojedynczościach" składających się na wspólnotę zagrożonych przez biowładzę odzierającą ewentualnie ich życie ze wszelkich ludzkich atrybutów, stale grożąc im śmiercią. Można byłoby również - w imię zachowania dawnych, fundujących tradycję liberalną ujęć — przejść do porządku nad tezą stosunkowo wielu już autorów, iż „podstawowym nośnikiem władzy są odpodmiotowione struktury prawa" ${ }^{26}$, a obóz koncentracyjny nie stanowi „,anomalii należącej do przeszłości” z perspektywy wychodzących z przeszłości i zabezpieczających się przez jej nawrotem współczesnych społeczeństw liberalno-demokratycznych, ale raczej jest swego rodzaju ukrytą matrycą, stając się wręcz nomos ,politycznej przestrzeni, w której obecnie żyjemy, nawet przestrzenią, która otwiera się, gdy stan wyjątkowy zaczyna stawać się regułą”, wreszcie „paradygmatem przestrzeni biopolitycznej”27.

Cóż zostało z Arystotelesa? Czy warto było trudzić się nad odsłanianiem kolejnych odniesień w poszukiwaniu dobra, normatywnego kontekstu dla aktywności prawodawcy? Czy pozostały już tylko „uchwały ludu”, na mocy których określa się los „ciała gatunkowego” lub ciał pojedynczych obozowych „muzułmanów", którymi mamy być również my, dumni uczestnicy liberalnych demokracji? Czy istotnie trwamy już, także my — tak oświeceni, uwzględniający dokonania poprzednich pokoleń nie tylko wszak w obszarze techniki czy technologii — w stanie, w którym „,normowanie i wykonywanie, tworzenie prawa jego stosowanie nie są [już] momentami dającymi się w jakikolwiek sposób odróżnić”?28 Czy przywódcy polityczni społeczeństw liberalno-demokratycznych istotnie przypominają już Führera nie jako nazwy urzędu w ,rozumieniu tradycyjnego prawa publicznego”, ale jako czegoś, „co bezpośrednio wypływa z jego osoby, ponieważ ta zbiega się z życiem ludu", dowolnego ludu kojarzonego z dowolnym społeczeństwem liberalno-demokratycznym, dla którego John Rawls skwapliwie szukał jeszcze pół wieku temu „konstytucji” jego „dobrego urządzenia”, być może wciąż tkwiąc w przebrzmiałej tradycji intelektualnej? Czy przywódcy ci

${ }^{26}$ M.M. Bogusławski, Homo sacer w świecie chaosu. Szkic o zwiazkach Agambena z Nancym i Serresem, [w:] W sprawie Agambena. Konteksty krytyki, red. Ł. Musiał et al., Poznań 2010, s. 215, przyp. 23.

27 G. Agamben, Homo sacer. Suwerenna władza i nagie życie, przeł. M. Salwa, Warszawa 2008, s. 227, 230, 233-234. Zauważmy, iż przywoływany autor, mający obóz za nomos ,politycznej przestrzeni, w której obecnie żyjemy" my, radujący się z dokonań i stanu liberalnej demokracji, traktował mieszkańców tego straszliwego miejsca (także zatem miejsca przez nas obecnie zajmowanego?; przez nas, uczestników liberalnej demokracji?) jako „ograbionych z jakiegokolwiek statusu politycznego i całkowicie sprowadzonych do nagiego życia", życia wyłącznie cielesnego; obóz to wszak „,przestrzeń, w której władza nie ma przez sobą niczego, z wyjątkiem czystego, niezapośredniczonego życia” (ibidem, s. 233).

${ }^{28}$ Ibidem, s. 236-237. 
mają swe słowo, swą wolę arbitralną za prawo, czy przyjęli już „ciało całościowe, ani publiczne, ani prywatne, ciało, którego życie jest samo w sobie w najwyższym stopniu polityczne"; ciało, które sytuuje się „,w punkcie zbiegu dzoē i bios, ciała biologicznego i ciała politycznego"29, które z powagą odróżniał Stagiryta? Czy wreszcie: „od obozów nie ma drogi powrotu do klasycznej polityki”? ${ }^{30}$

\section{Bibliografia}

Agamben G., Homo sacer. Suwerenna władza i nagie życie, przeł. M. Salwa, Warszawa 2008. Arystoteles, Polityka, przeł. L. Piotrowicz, [w:] idem, Dzieła wszystkie, t. VI, Warszawa 2001. Bogusławski M.M., Homo sacer $w$ świecie chaosu. Szkic o zwiazkach Agambena z Nancym i Serresem, [w:] W sprawie Agambena. Konteksty krytyki, red. Ł. Musiał et al., Poznań 2010. Foucault M., Trzeba bronić spoleczeństwa. Wykłady w Collège de France, 1976, przeł. M. Kowalska, Warszawa 1998.

Szlachta B., O problematyczności uchwat ludu jako źródet prawa (na przykładzie Polityki Arystotelesa), [w:] Polska-Europa-świat. Prace politologiczne i historyczne. Ksiega jubileuszowa ofiarowana Profesorowi Edwardowi Olszewskiemu z okazji 70. rocznicy urodzin, red. M. Marczewska-Rytko, S. Stępień, Lublin 2012.

\section{LIBERAL DEMOCRACY AS A CONCENTRATION CAMP? SOME REMARKS ON PROLIFERATING (SCANDALOUS?) OPINIONS}

\section{Summary}

Aristotelian distinction dzoē and bios is very often present in reflections on a condition of contemporary liberal-democratic Western societies. Some authors suggest that processes in modern or even postmodern societies lead to new conceptions of power and combine new conceptions of law. Thanks to this in biopolitical reflections, above all in Foucault's and Agamben's writings, we could see liberal democracy as a concentration camp, without individual freedom, but with strictly controlled human bodies. Article presents some aspects of this dramatic visions.

Keywords: politics, law, Liberal democracy, biopolitics.

Bogdan Szlachta

bogdan.szlachta@uj.edu.pl

\footnotetext{
${ }^{29}$ Ibidem, s. 251.

${ }^{30}$ Ibidem, s. 256.
}

Studia nad Autorytaryzmem i Totalitaryzmem 38, nr 4, 2016 (C) for this edition by CNS 